\title{
The effects of long-term exclusion of the limpet Cymbula oculus (Born) on the distribution of intertidal organisms on a rocky shore
}

\author{
Gavin W. Maneveldt*, Rosemary C. Eager and Aghmat Bassier \\ Department of Biodiversity and Conservation Biology, University of the Western Cape, Private Bag X17, \\ Bellville 7535, South Africa
}

*Corresponding author: gmaneveldt@uwc.ac.za

\begin{abstract}
Zonation patterns on rocky shores are typically as a result of both physical factors and biological interactions. Physical factors generally set the upper limits of species distributions, while biological interactions generally set their lower limits. Recent research has shown, however, that biological factors often can also influence the upward recruitment and colonisation by species. While such evidence exists in the international literature, very little experimental evidence exists for South Africa. This study provided experimental evidence for the biological effects of long-term exclusion (2003-2008) of the South African herbivorous limpet Cymbula oculus (Born), on the community structure of the Kalk Bay rocky intertidal. To demonstrate this, an herbivore exclusion experiment was set up in the mid-Eulittoral zone in May 2003. Initially, all herbivores were removed from the exclusion plots; after one year, only C. oculus individuals recruiting into the plots were continually removed. Algal recruitment (percent cover abundance) was determined monthly for the first 12 months and then annually thereafter, while invertebrate recruitment (density) was monitored only annually.
\end{abstract}

The results firstly show that the natural density of C. oculus had increased dramatically during the first year (from $4.87 \pm 1.09$ individuals $\mathrm{m}^{-2}$ to $12.35 \pm 1.70$ individuals $\mathrm{m}^{-2}, \mathrm{p}$ $=0.001$ ). Secondly, grazing by C. oculus is the primary biological factor preventing the recruitment and colonization of macroalgae and some invertebrates onto the Kalk Bay intertidal. Not only does herbivory by C. oculus prevent recruitment and colonization, but it also decreases algal diversity and prevents algal succession. Within the midEulittoral zone of the Kalk Bay rocky intertidal, herbivory by C. oculus is thus more important in shaping this marine community than physical factors associated with desiccation stress.

Keywords/phrases: diversity, herbivory, recruitment, South Africa, succession, zonation 


\section{Introduction}

The vertical distribution of plants and animals between tide-marks on rocky shores is termed zonation, and is usually evident by the dominance of various organisms at different heights on the shore (Stephenson and Stephenson 1949, 1972, Lubchenco 1980, Dring 1982, Little and Kitching 1996). Zonation patterns are typically established as a result of both physical disturbances and biological interactions (Stephenson and Stephenson 1949, Connell 1972, Lubchenco 1980). Physical factors such as high temperatures, high light intensities and desiccation stress were originally thought to be the primary factors structuring rocky shore communities (Dayton 1971, Connell 1972, Lubchenco 1980, Branch and Branch 1981). It is commonly accepted that physical factors tend to be more prevalent at high shore levels, where extremes of wave action and water level, low and high salinity, high solar radiation and desiccation stress are common (Stephenson and Stephenson 1949, 1972, Connell 1972, Branch and Branch 1981). Biological factors such as competition (Dayton 1971, Hawkins and Harkins 1985, Branch 1985a, Farrell 1991), herbivory (Paine and Vadas 1969, Dayton 1971, Nicotri 1977, Lubchenco and Gaines 1981, Anderson and Underwood 1997), predation (Paine and Vadas 1969, Dayton 1975, Lubchenco and Menge 1978), as well as larval settlement (Dayton 1971, Little and Kitching 1996) are generally believed to have greater impacts on species at lower shore levels, when physical stresses are minimal (Connell 1972, Lubchenco 1980, Branch and Branch 1981).

Physical factors thus generally set the upper limits of species distributions, while biological interactions generally set their lower limits (Dayton 1971, Connell 1972, Branch 1976, Raffaelli and Hawkins 1996). Recent research (e.g. Lubchenco 1980, Underwood 1980, Underwood and J ernakoff 1981, Creese and Underwood 1982, Little and Kitching 1996, Boaventura et al. 2002) has shown, however, that biological factors often can determine the upward recruitment and colonization by species and that it can be of vital importance in the vertical distribution of algal assemblages. While such evidence is increasingly becoming known in the international literature, very little evidence exists for Southern Africa (see e.g. Dye 1993, 1995). Much evidence from South Africa is anecdotal, coming from the more popular literature (e.g. Branch and Branch 1981, Branch 1985a).

South African rocky shores have been given a unique terminology by Branch and Branch (1981). High up on the shore on the west and south coast is the infratidal (or Supralittoral fringe) zone, locally known as the Littorina zone, which is dominated by tiny Afrolittorina knysnaensis (Philippi) snails. This zone is followed by the upper Eulittoral zone (upper Balanoid) largely dominated by barnacles, more so on the south coast than the west coast. Next is the mid-Eulittoral zone (lower Balanoid), mainly comprising dense beds of macroalgae. On the south coast, scattered associations of the territorial limpet Scutellastra longicosta (Lamarck) and its garden of Ralfsia verrucosa (Areschoug) Areschoug are found among the macroalgal beds. The lowest zone in the intertidal is the lower Eulittoral zone. On the south coast this zone is characterised by dense aggregations of the territorial, gardening limpet, S. cochlear (Born) and is 
consequently named the Cochlear zone. The west coast shows a similar zonation pattern, but here the lower Eulittoral zone is known as the Cochlear/ Argenvillei zone as S. cochlear shares this zone with S. argenvillei (Krauss), which occurs in equally dense aggregations.

Kalk Bay (in False Bay) has a typical west-south coast transition zonation pattern bearing elements of both the west and south coasts (Stephenson and Stephenson 1972). Here, however, the dense beds of macroalgae that are meant to be common in the midEulittoral zone (see Branch and Branch 1981), are lacking. The zone is instead occupied by high densities of the herbivorous limpet, Cymbula oculus (Born) (GW Maneveldt, pers. obs.) and it was suspected that this limpet may be the cause for the low to nonexistent macroalgal cover in this zone at Kalk Bay. It was thus hypothesised that grazing by this limpet has a profound effect on the distribution of intertidal organisms (notably macroalgal species) of the Kalk Bay mid-Eulittoral zone. It was therefore the purpose of this study to determine experimentally the effects of long-term exclusion of C. oculus on the community structure of the Kalk Bay rocky shore.

\section{Material and Methods \\ Study site}

The experiment was setup in the mid-Eulittoral zone at Kalk Bay (34 $08^{\prime} \mathrm{S}, 18^{\circ} 27^{\prime} \mathrm{E}$ ) in the Western Cape Province, South Africa. The site is moderately exposed to the south-easterly winds as well as to wave action. At this site, C. oculus is the most obvious herbivore in the mid-Eulittoral zone. The limpet is a generalist grazer and is widespread on flat surfaces which enable it to be an efficient grazer that covers vast areas (Branch 1976, 1985a). While it was not common to see S. longicosta, an observation atypical of the literature (see Branch and Branch 1981), it was common to find juvenile S. longicosta finding refuge on the shells of $\mathrm{C}$. oculus at this site. At Kalk Bay, macroalgae were virtually absent from the mid-Eulittoral zone.

\section{Natural Algal percent cover and invertebrate densities and biomass}

Natural algal cover and invertebrate densities were estimated and averaged at regular 2 $\mathrm{m}$ intervals along three transect lines, running parallel to the zone and spaced $2 \mathrm{~m}$ apart, using a $0.5 \times 0.5 \mathrm{~m}$ quadrat ( $\mathrm{n}=24$ quadrats). Animals from these quadrats (Table 1) were collected and brought back to the laboratory for biomass determinations. These measurements were determined annually for five years during March of each year. The density of S. longicosta was typically very low on the open rocky platforms at Kalk Bay (GW Maneveldt, pers. obs.). A number of adult C. oculus, however, were observed to bear many juvenile S. longicosta on their shells. To determine the relative importance of C. oculus serving as a secondary substratum for S. longicosta, a frequency measure was determined during September 2007. To determine the frequency of S. longicosta on the shells of $\mathrm{C}$. oculus, the densities of these interactions were recorded within a $0.5 \mathrm{~m}$ radius at regular $2 \mathrm{~m}$ intervals along three transect lines running parallel to the zone and that were spaced $2 \mathrm{~m}$ apart ( $\mathrm{n}=12$ radii, 42 interactions). 
Table 1. Taxa surveyed during the study, their main features and their presence (+) and/or absence (-) in control and exclusion plots. Diatoms have been excluded because they represent an assemblage (not a taxon) that is present in both control (as "bare rock") and exclusion plots.

\begin{tabular}{|c|c|c|c|}
\hline Taxa & Main Feature & $\begin{array}{l}\text { Control } \\
\text { plots }\end{array}$ & $\begin{array}{l}\text { Exclusion } \\
\text { plots }\end{array}$ \\
\hline \multicolumn{4}{|l|}{ Algae: } \\
\hline Ceramium sp. & Turfy red alga & - & + \\
\hline Cyanobacteria & $\begin{array}{l}\text { Microscopic } \\
\text { filamentous } \\
\text { green alga }\end{array}$ & - & + \\
\hline $\begin{array}{l}\text { Gelidiumpristoides (Turner) } \\
\text { Kützing }\end{array}$ & Turfy red alga & - & + \\
\hline $\begin{array}{l}\text { Gigartina polycarpa } \\
\text { (Kützing) Setchell et Gardner }\end{array}$ & Foliose red alga & - & + \\
\hline $\begin{array}{l}\text { Nothogenia erinacea } \\
\text { (Turner) Parkinson }\end{array}$ & Foliose red alga & - & + \\
\hline Porphyra spp. & Foliose red alga & - & + \\
\hline $\begin{array}{l}\text { Ralfsia verrucosa } \\
\text { (Areschoug) Areschoug }\end{array}$ & $\begin{array}{l}\text { Encrusting brown } \\
\text { alga }\end{array}$ & + & + \\
\hline Ulva intestinalis Linnaeus & Foliose green alga & - & + \\
\hline Ulva rigida C. Agardh & Foliose green alga & - & + \\
\hline Number of algal taxa: & & 1 & 9 \\
\hline $\begin{array}{l}\text { Invertebrates: } \\
\text { Austromegabalanus } \\
\text { cylindricus (Gmelin) }\end{array}$ & Barnacle-filter feeder & - & + \\
\hline
\end{tabular}




\begin{tabular}{|c|c|c|c|}
\hline Chthamalus dentatus Krauss & Barnacle-filter feeder & - & + \\
\hline Cymbula oculus (Born) & Limpet - herbivore & + & - \\
\hline $\begin{array}{l}\text { Mytilus galloprovincialis } \\
\text { Lamarck }\end{array}$ & Mussel - filter feeder & - & + \\
\hline Oxystele variegata (Anton) & Winkle- herbivore & + & + \\
\hline Oxystele tigrina (Anton) & Winkle- herbivore & + & - \\
\hline Patiriella exigua (Lamarck) & Sea star - herbivore & + & + \\
\hline $\begin{array}{l}\text { Scutellastra granularis } \\
\text { (Linnaeus) }\end{array}$ & Limpet - herbivore & + & + \\
\hline $\begin{array}{l}\text { Scutellastra longicosta } \\
\text { (Lamarck) }\end{array}$ & Limpet - herbivore & + & + \\
\hline $\begin{array}{l}\text { Siphonaria capensis Quoy et } \\
\text { Gaimard }\end{array}$ & $\begin{array}{l}\text { False limpet } \\
\text { herbivore }\end{array}$ & + & + \\
\hline Tetraclita serrata Darwin & Barnacle-filter feeder & + & + \\
\hline $\begin{array}{l}\text { Watersipora subovoidea } \\
\text { Ryland }\end{array}$ & Bryozoan-filter feeder & - & + \\
\hline Number of invertebrate taxa: & & 8 & 10 \\
\hline Total number of taxa & & 9 & 19 \\
\hline
\end{tabular}

\section{Experimental design}

To determine the effects of grazing by C. oculus on the distribution of algae and other invertebrates, an herbivore exclusion experiment was set up in May 2003. Exclusion plots were set up randomly and confined to the mid-Eulittoral zone. The substrata where exclusion plots were to be established had their fringes burnt with a blow torch and antifouling paint (Seaguardian Anti-fouling Marine Paint, Jotun (Pty) Ltd, Blackheath, Western Cape Province, South Africa) was used to paint the fringes around exclusion plots. This was necessary to allow the paint to adhere to the rocky substrate. All grazers were removed from exclusion plots. Exclusion plots were numbered using stainless steel screws and brass tags. Control plots were identified and marked in the same way, but were not painted or ever manipulated. Twenty-four exclusion and twenty-four control plots were set up in pairs i.e. each exclusion plot was paired with its 
own control plot. Plots were $0.3 \times 0.3 \mathrm{~m}$ along their inner dimensions and both control and experimental plots contained no visible foliose macroalgae at the start of the experiment. Plots were maintained monthly throughout the five years of the experiment. Initially, all visible herbivores recruiting into the exclusion plots were removed. After one year, only C. oculus individuals were removed. From the exclusion plots, algal recruitment (percent cover abundance) was determined monthly for the first 12 months and then annually thereafter, while invertebrate recruitment (density only) was determined only annually. From the control plots, algal and invertebrate (densities and biomass) recruitment was determined annually.

Within the first year, one exclusion plot was continually breached by herbivores because of the inability of the antifouling paint to remain adherent to the substratum between maintenance periods. A further eight exclusion plots either lost their tags, or had their painted borders damaged through severe storm activity during the winter of 2006. Subsequent data analyses were thus performed only on fully intact pairs of exclusion and control plots so that $n=23$ for the period 2003-2006 and $n=15$ for the period 2007-2008.

\section{Statistical analysis}

To show the relative importance of the different invertebrate species in the natural community over time, multiple paired sample t-tests were performed on both the density and biomass values for all possible species pairs (28) of the eight invertebrate species encountered, using SAS. Mean values were sorted in ascending order and the Pvalues for the t-tests used to assign significance letters (a's, b's, etc). To verify these results, paired sample t-tests were also performed on the log transformed data. To determine if there were differences between natural quadrats and control plots, and control and exclusion plots, paired-sample (natural vs control; control vs exclusion) ttests were also performed for each species that occurred in both the natural quadrats and control plots, and control and exclusion plots; this was done for each year of the experiment. For all tests performed a $5 \%$ significance level was applied and so differences amongst treatments were considered statistically significant at $\mathrm{p}<0.05$. Except for the frequency measures, all data are expressed as means \pm standard errors (se).

\section{Results}

\section{Natural and control plot algal cover and invertebrate densities and biomass}

For all species observed, there were no statistical differences between their percent cover abundance (algae), densities and biomass (invertebrates) between natural quadrats and control plots (all combinations produced $\mathrm{p}>0.05$ ). The mid-Eulittoral zone was primarily comprised of "bare rock" (bare rock here refers to the absence of visible macroalgae, but includes microalgal biofilms) with only a small percentage of the encrusting brown alga, R. verrucosa evident (Figure 1, Tables $1 \& 2$ ). Macroalgae were thus generally absent from the mid-Eulittoral at Kalk Bay. While many invertebrates 
were encountered, their numbers and biomass fluctuated from year to year (Figure 2, Table 2). Cymbula oculus, however, was by far the most important grazer on the Kalk Bay mid-Eulittoral zone, particularly in the latter years (see biomass data, Figure 2). Notably, the natural density of C. oculus increased dramatically during the first year of the study (from $4.87 \pm 1.09$ individuals $\mathrm{m}^{-2}$ to $12.35 \pm 1.70$ individuals $\mathrm{m}^{-2}, \mathrm{p}=0.001$ ). Scutellastra longicosta was low in density and biomass. While a high frequency of juvenile S. longicosta encountered was found epizoically on the shells of adult C. oculus in 2007 (66.7\% 10 individuals $\mathrm{m}^{-2}$ ), this did not translate into high recruitment onto the primary substratum in the subsequent year (Figure 3, Table 2).

Figure 1: Natural percent cover abundance of algae in the mid-Eulittoral zone at Kalk Bay determined during March of each year (error bars are too small to view).

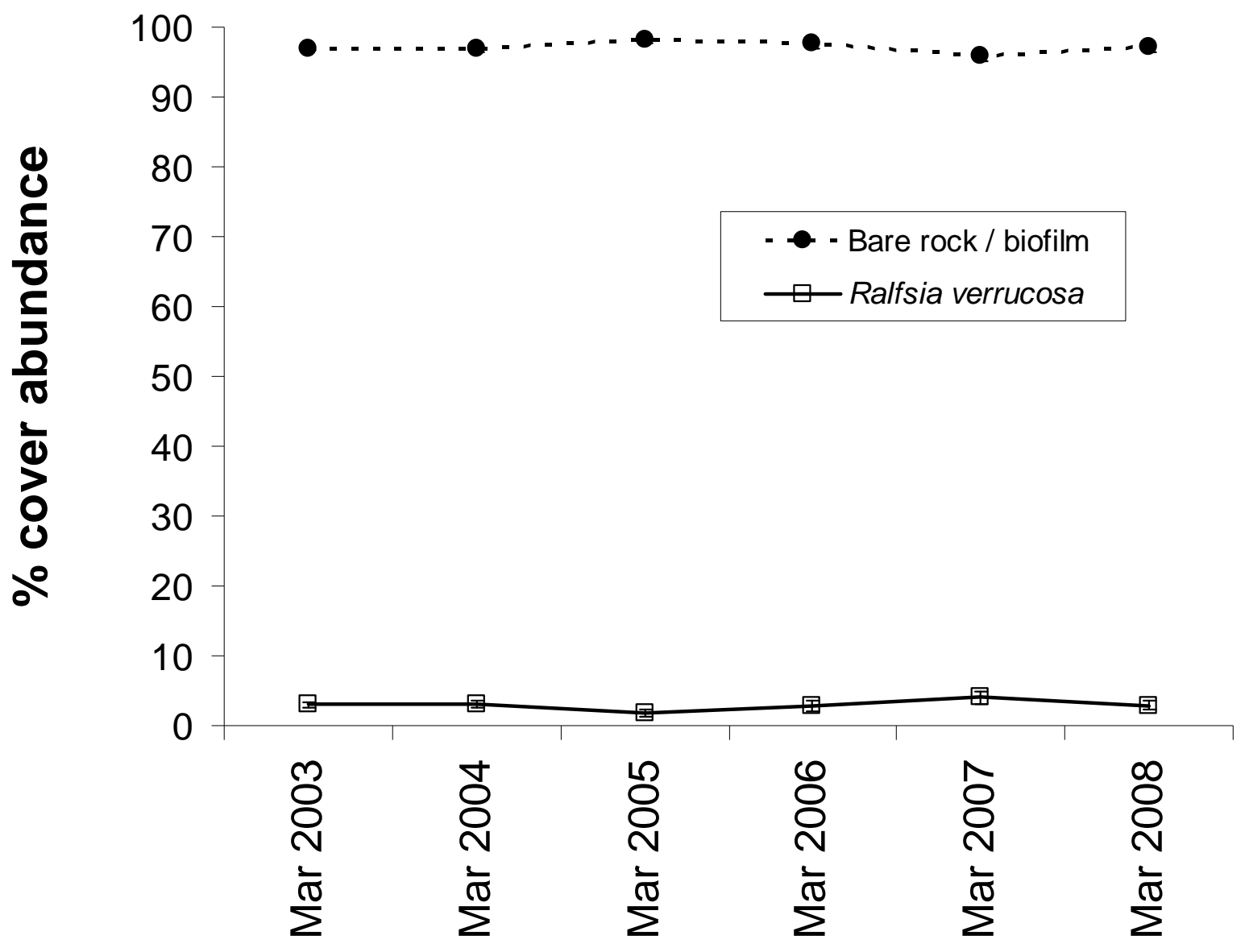


Table 2. The statistical variation in percent cover abundance (for algae) and density (for invertebrates) between control and exclusion plots over time given for all taxa found to occur in both sets of plots as determined by the paired sample t-Tests. All data are considered statistically significant at $\mathrm{p}<0.05$ (ns $=$ not significant).

\begin{tabular}{lll}
\hline Taxa/Time & $\begin{array}{l}\text { Control plots } \\
(\text { mean } \pm \text { s.e. })\end{array}$ & $\begin{array}{l}\text { Exclusion plots } \\
(\text { mean } \pm \text { s.e. })\end{array}$ \\
\hline
\end{tabular}

\begin{tabular}{lll}
\hline Algae: & & \\
$\begin{array}{l}\text { Ralfsia verrucosa } \\
\text { start }\end{array}$ & & \\
& $2.96 \pm 0.48$ & 0.00 \\
end year 1 & $\mathrm{p}<0.001, \mathrm{df}=22$ & \\
& $3.09 \pm 0.42$ & $1.78 \pm 1.07$ \\
end year 2 & $\mathrm{ns}(\mathrm{p}=0.13, \mathrm{df}=22)$ & \\
& $1.74 \pm 0.56$ & $19.26 \pm 5.30$ \\
end year 3 & $\mathrm{p}<0.01, \mathrm{df}=22$ & \\
& $2.87 \pm 0.84$ & $29.13 \pm 4.40$ \\
end year 4 & $\mathrm{p}<0.001, \mathrm{df}=22$ & \\
& $4.00 \pm 0.89$ & $35.47 \pm 4.67$ \\
end year 5 & $\mathrm{p}<0.001, \mathrm{df}=14$ & \\
& $2.93 \pm 0.70$ \\
& $\mathrm{p}<0.001, \mathrm{df}=14$ & $39.13 \pm 5.56$ \\
\end{tabular}

Invertebrates:

Oxystele variegata

$\begin{array}{lll}\text { start } & 3.65 \pm 1.58 & 0.00 \\ & \mathrm{p}=0.02, \mathrm{df}=22 & \\ \text { end year } 1 & 5.74 \pm 1.78 & 0.00 \\ & \mathrm{p}<0.01, \mathrm{df}=22 & \\ \text { end year 2 } & 8.52 \pm 3.40 & 6.09 \pm 3.86 \\ & \mathrm{~ns}(\mathrm{p}=0.65, \mathrm{df}=22) & \\ \text { end year 3 } & 11.65 \pm 2.94 & 5.22 \pm 3.14 \\ & \mathrm{p}=0.03, \mathrm{df}=22 & \\ \text { end year } 4 & 13.73 \pm 4.97 & 2.67 \pm 1.82 \\ & \mathrm{p}=0.03, \mathrm{df}=14 & \\ \text { end year 5 } & 12.53 \pm 3.74 & 2.07 \pm 1.12 \\ & \mathrm{p}=0.01, \mathrm{df}=14 & \end{array}$


Patiriella exigua

start

end year 1

end year 2

end year 3

end year 4

end year 5

Scutellastra granularis

start

end year 1

end year 2

end year 3

end year 4

end year 5

Scutellastra longicosta

start

end year 1

end year 2

end year 3

end year 4

end year 5

Siphonaria capensis

start
$10.61 \pm 3.33$

0.00

$\mathrm{p}<0.01, \mathrm{df}=22$

$14.26 \pm 4.23$

0.00

$\mathrm{p}<0.001, \mathrm{df}=22$

$8.61 \pm 3.66$

0.00

$\mathrm{p}=0.01, \mathrm{df}=22$

$13.91 \pm 4.18$

0.00

$\mathrm{p}<0.01, \mathrm{df}=22$

$12.00 \pm 5.52$

0.00

$\mathrm{p}=0.02, \mathrm{df}=14$

$10.13 \pm 3.53$

$5.87 \pm 2.60$

ns $(\mathrm{p}=0.20, \mathrm{df}=14)$

$0.52 \pm 0.29$

0.00

ns $(\mathrm{p}=0.08, \mathrm{df}=22)$

$0.53 \pm 0.38$

0.00

ns $(\mathrm{p}=0.19, \mathrm{df}=22)$

$0.52 \pm 0.38$

0.00

ns $(\mathrm{p}=0.19, \mathrm{df}=22)$

$0.52 \pm 0.29$

0.00

ns $(\mathrm{p}=0.08, \mathrm{df}=22)$

$0.27 \pm 0.27$

$0.73 \pm 0.73$

ns $(\mathrm{p}=0.28, \mathrm{df}=14)$

$0.53 \pm 0.36$

$2.20 \pm 1.18$

$\mathrm{ns}(\mathrm{p}=0.11, \mathrm{df}=14)$

$1.22 \pm 0.39$

0.00

$\mathrm{p}<0.01, \mathrm{df}=22$

$1.57 \pm 0.97$

0.00

$\mathrm{p}<0.01, \mathrm{df}=22$

$1.22 \pm 0.39$

$11.87 \pm 2.64$

$\mathrm{p}<0.001, \mathrm{df}=22$

$28.22 \pm 3.40$

$1.74 \pm 0.49$

$\mathrm{p}<0.001, \mathrm{df}=22$

$1.60 \pm 0.52$

$36.47 \pm 3.25$

$\mathrm{p}<0.001, \mathrm{df}=14$

$1.87 \pm 0.53$

$43.53 \pm 3.46$

$\mathrm{p}<0.001, \mathrm{df}=14$

$14.00 \pm 4.78$

0.00 


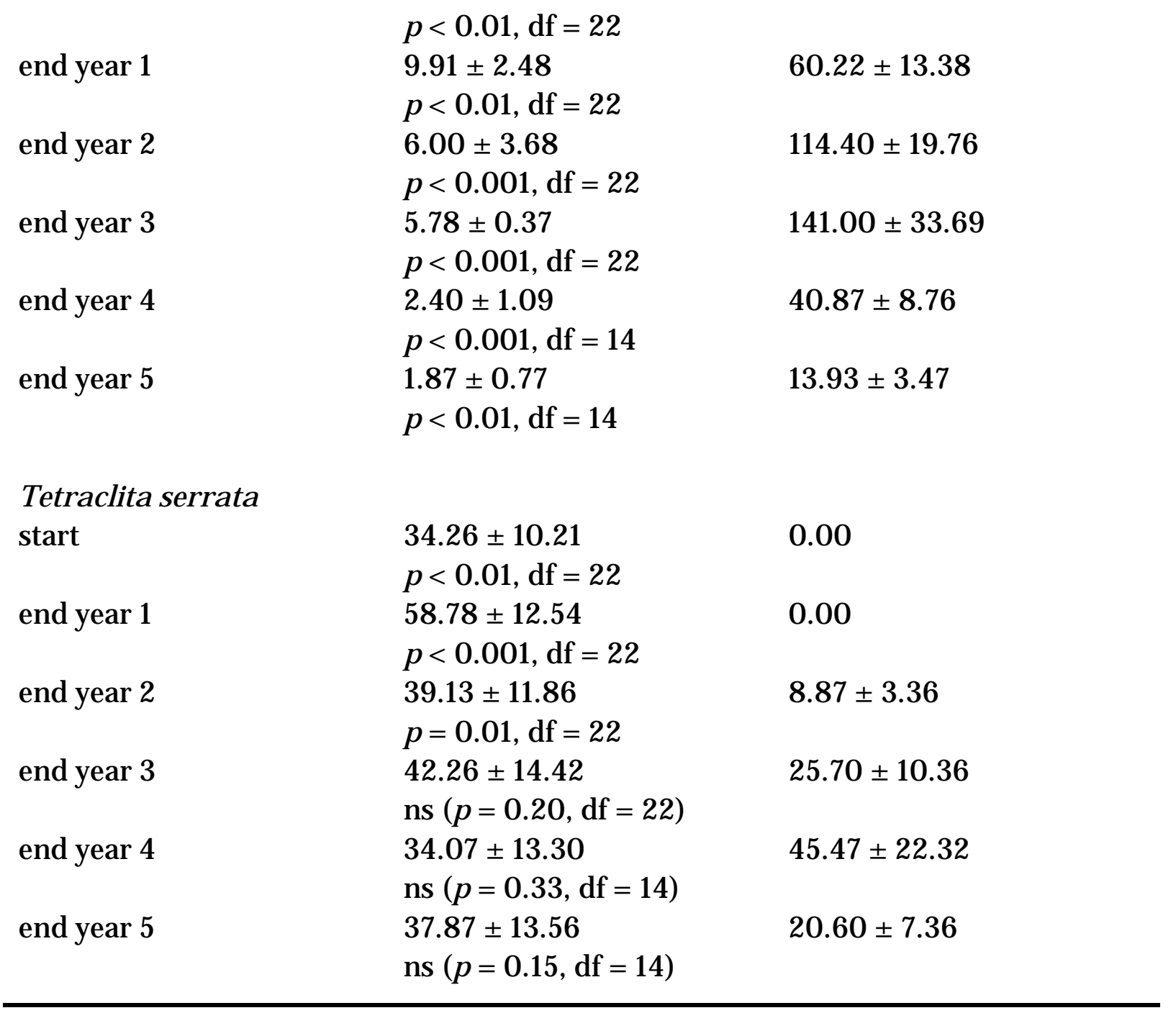

Figure 2: Natural invertebrate densities and biomass in the mid-Eulittoral zone for the entire experimental period determined during March of each year. The solid bars are the density and biomass estimations for $\mathrm{C}$. oculus. Bars with the same letters are not statistically different. 

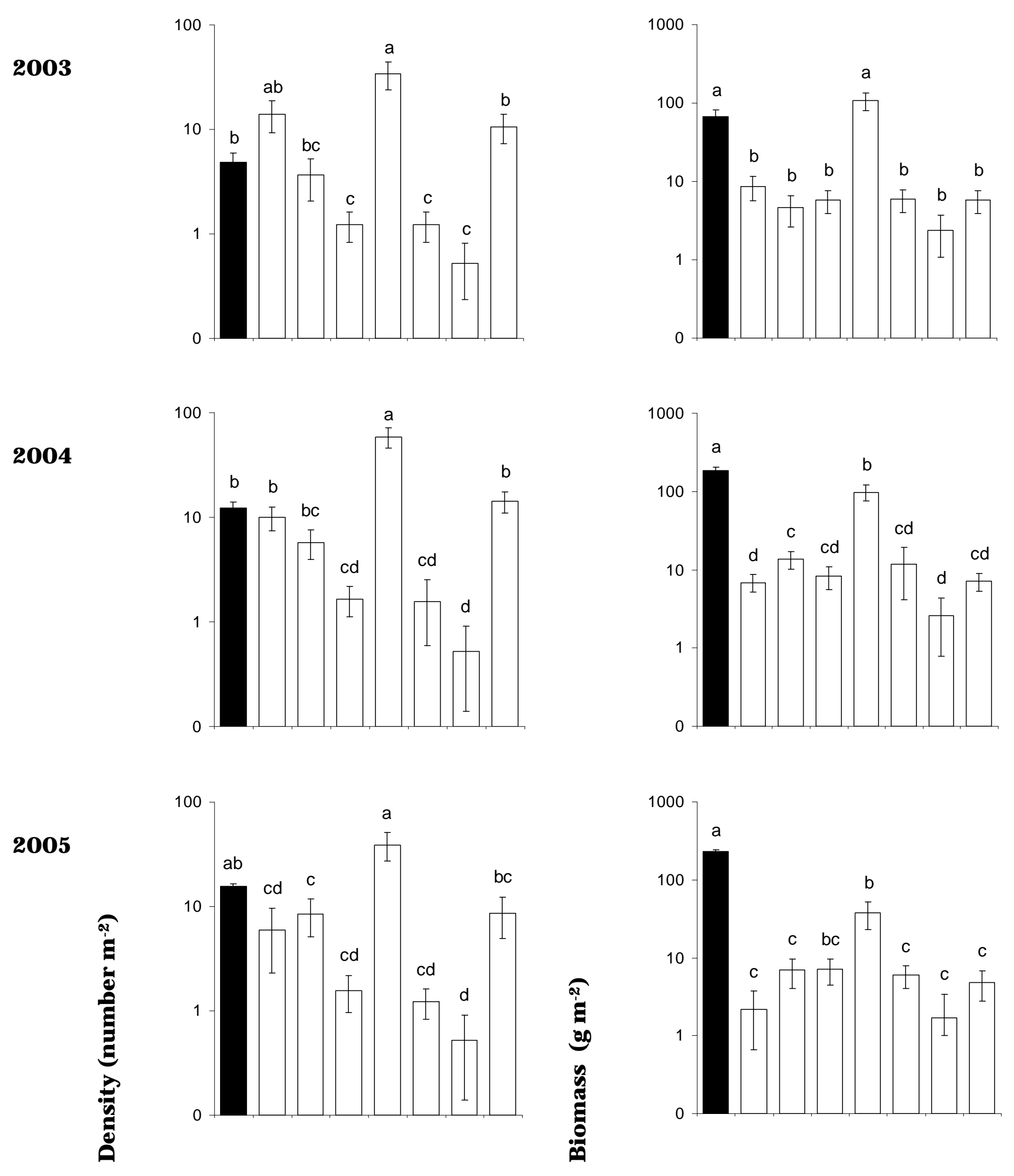

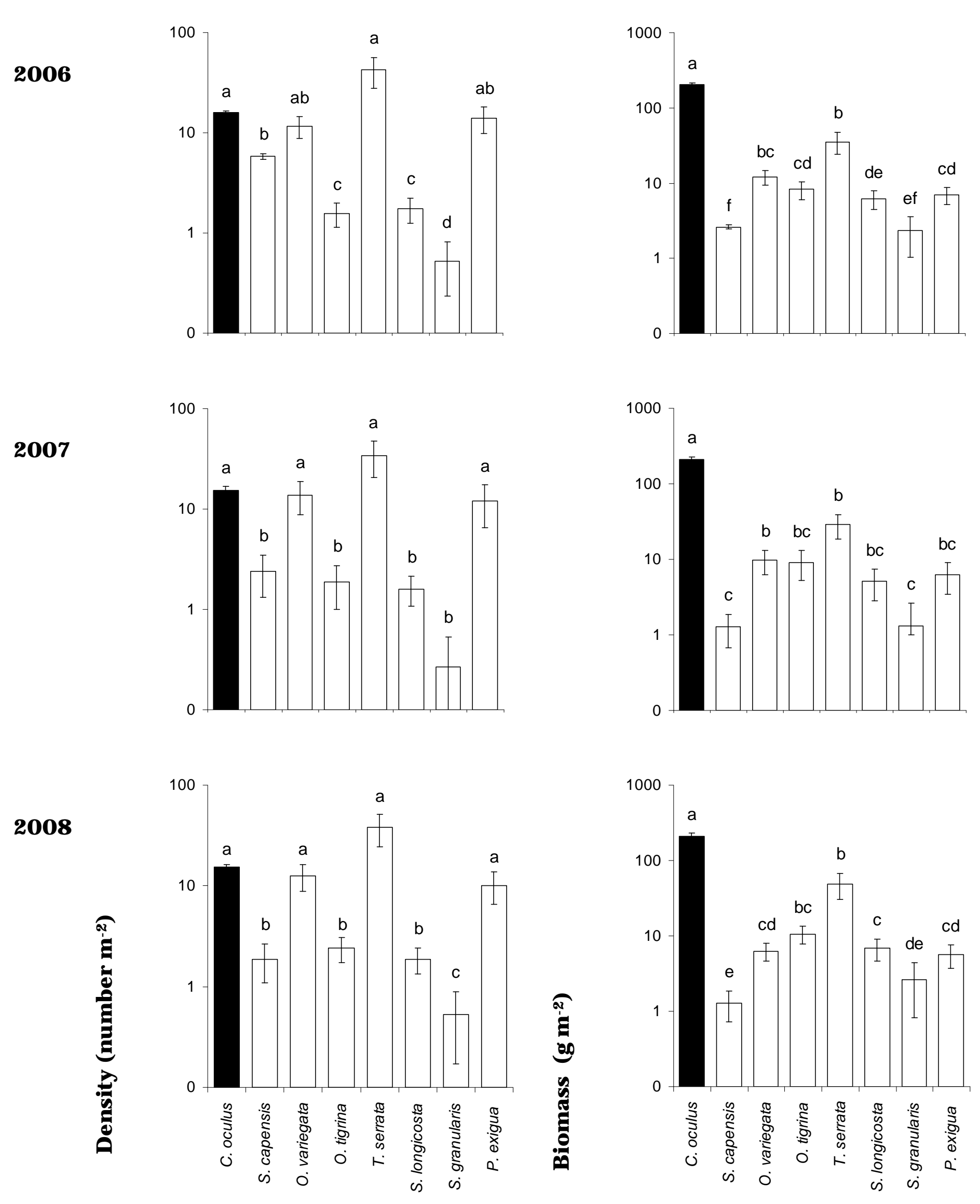
Figure 3: The relative frequencies (number of individuals) of S. longicosta and C. oculus on the rocky substratum at Kalk Bay, and the proportion of C.oculus individuals that were found to bear juvenile individuals of S. longicosta on their shells.

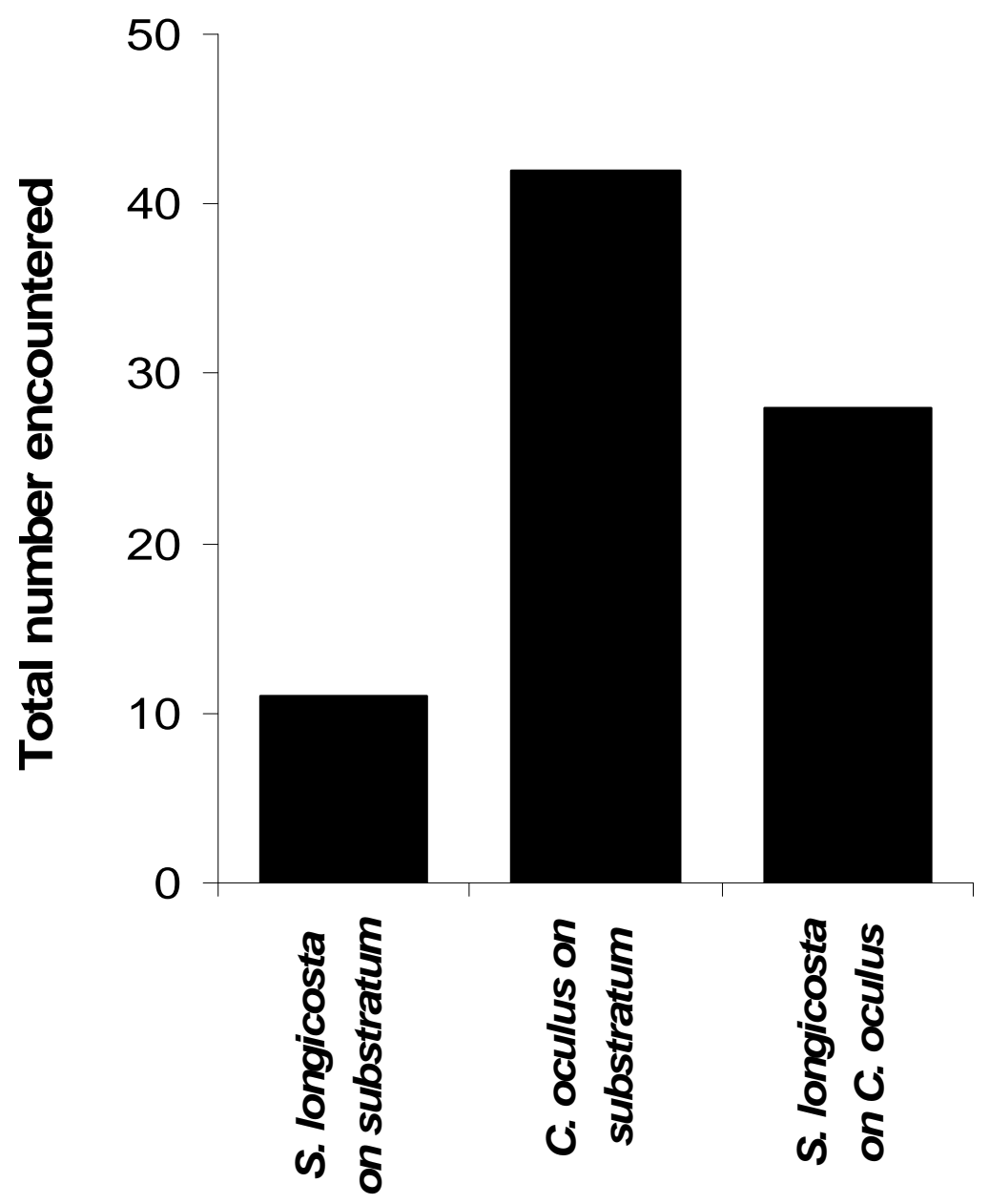

Effects of herbivore exclusion

First year 
Exclusion of grazers from the mid-Eulittoral zone resulted in an immediate increase in algal diversity and percent cover abundance (Figure 4, Table 1). This was in clear contrast to the control plots that were still devoid of foliose macroalgae. Proliferation of diatoms (from "bare rock") occurred immediately following herbivore exclusion. This was short-lived and soon followed by recruitment of the opportunistic green algae, Ulva rigida C. Argardh and then U. intestinalis Linnaeus. Cyanobacteria and Porphyra spp. also recruited for a short period of time, but then declined as U. intestinalis dominated the exclusion plots toward the end of the first year.

Figure 4: Algal recruitment (percent cover abundance) into the C. oculus exclusion plots during the first year of the study.

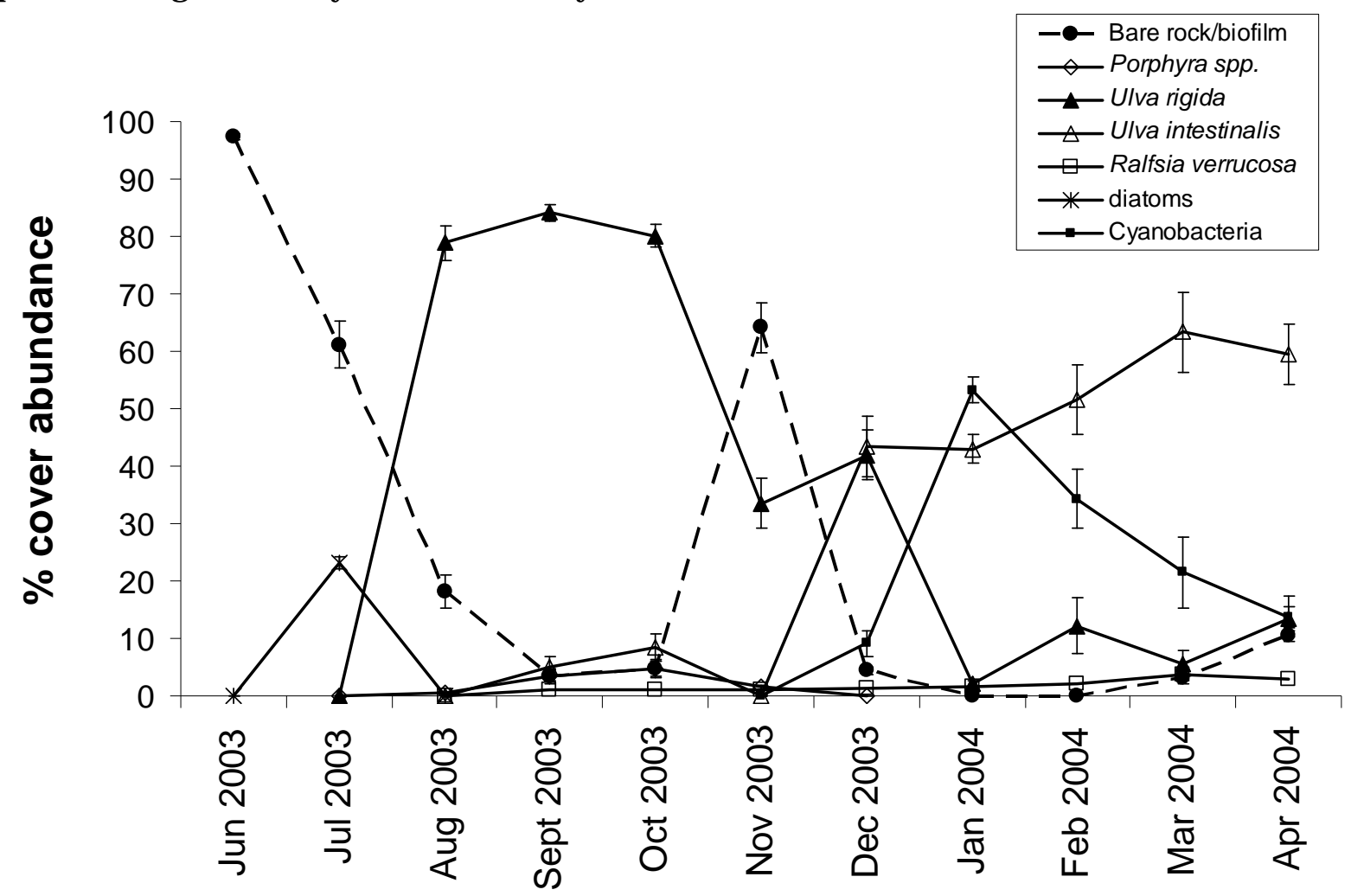

\section{Years 2 - 5}

Algal succession occurred after the first year, with the opportunistic alga U. intestinalis slowly being replaced by the later successional R. verrucosa and Gelidium pristoides (Turner) Kützing (Figure 5, Tables $1 \& 2$ ). With time, an increase in algal diversity was observed in the experimental plots. "Bare rock" dramatically declined within the first year following herbivore exclusion, but increased and then again decreased in subsequent years (Figure 5). This initial increase coincided with the recruitment of other invertebrates (Figure 6, Table 2), particularly the false limpet Siphonaria capensis Quoy and Gaimard that created cleared space in the exclusion plots. Over time, the diversity of invertebrates increased in the exclusion plots. The barnacles Austromegabalanus cylindricus (Gmelin) and Chthamalus dentatus Krauss, the bryozoan Watersipora subovoidea Ryland, and the mussel Mytilus galloprovincialis 
Lamarck were even recorded in the exclusion plots (Figures $5 \& 6$, Table 1). Austromegabalanus cylindricus has only been observed to occur in the infratidal and immediate subtidal zones at Kalk Bay, and not on the exposed rocky intertidal platforms (GW Maneveldt, pers. obs.). Chthamalus dentatus is commonly found on exposed flats in the upper intertidal zone, W. subovoidea subtidal and beneath boulders and along shaded overhangs in the intertidal zone, and M. galloprovincialis in dense bands in the infratidal and low intertidal zone (Branch et al. 1994, J ones 2008); we had not previous observed these invertebrates on the mid-shore. With time, S. capensis and C. dentatus decreased in numbers notably as the limpet $\mathrm{S}$. longicosta started recruiting into the exclusion plots. In particular, there was also a strong positive correlation between the percent cover abundance of the encrusting alga $\mathrm{R}$. verrucosa and the density of S. longicosta $(r=0.98, p<0.01)$.

While C. oculus prevented the recruitment of some invertebrates, others were not positively influenced by the limpets' absence (Tables $1 \& 2$ ). Neither species of Oxystele (O. tigrina [Anton] and O. variegata [Anton]) benefited from the absence of C. oculus. While O. tigrina remained absent from the exclusion plots, $\mathrm{O}$. variegata were higher in numbers in control plots compared to exclusion plots. This was similarly so for Tetraclita serrata Darwin and Patiriella exigua (Lamarck), although these latter two species did increase in densities in the exclusion plots toward the end of the experimental period. Scutellastra granularis (Linnaeus) remained equally low in both control and exclusion plots throughout the experimental period.

Figure 5: Annual recruitment (percent cover abundance) of algae and the bryozoan W. subovoidea into the C. oculus exclusion plots. 


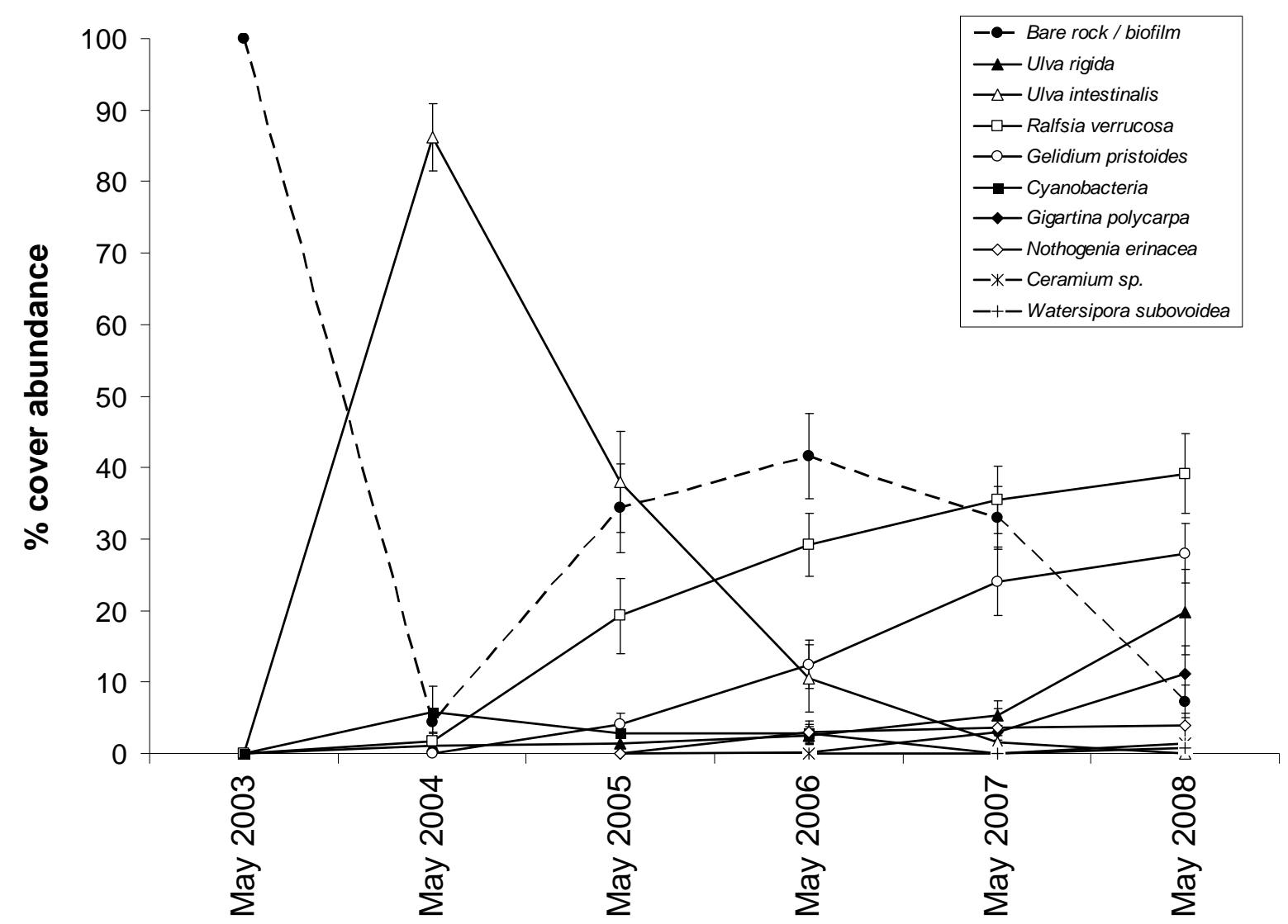

Figure 6: Annual invertebrate recruitment (density) into the C. oculus exclusion plots. Note that there are no data for 2003 as this was the starting year of the experiment.

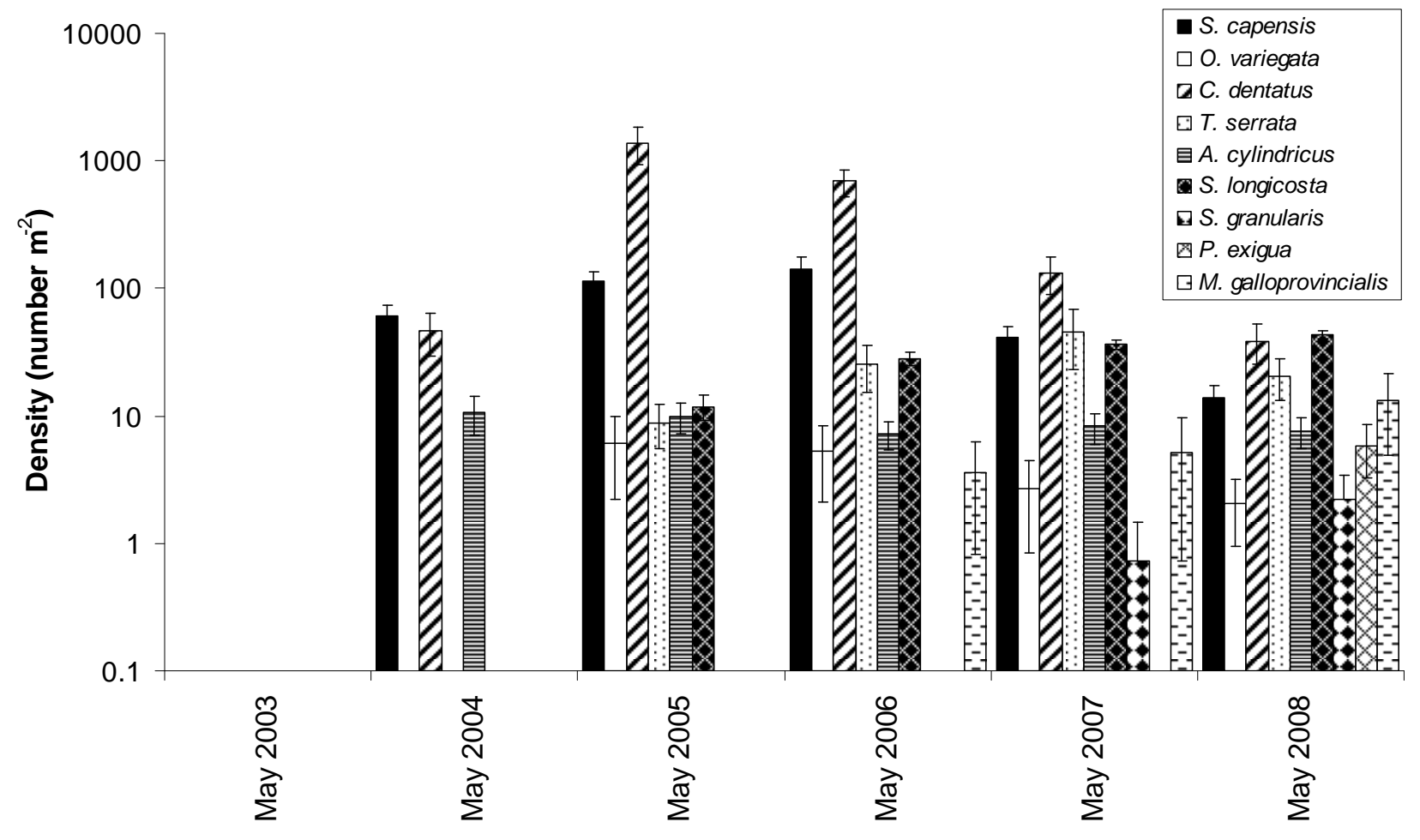

\section{Discussion}


Many studies (e.g. Dayton 1971, Branch 1975, 1981, 1985b, Underwood 1980, 1992) on rocky intertidal habitats have addressed the interplay between physical and biological factors. For many years it was asserted that only physical stresses associated with aerial exposure controlled species' recruitment and colonization up the shore, particularly that of algae (Stephenson and Stephenson 1949). Although physical stress may, for example, suppress algal growth in the upper reaches of the intertidal (Underwood 1980, Branch and Branch 1981, Branch 1985a), biological factors have recently been shown to play an important role in structuring upper shore communities on rocky shores (Underwood 1980, Underwood and J ernakoff 1981, 1984, Dye 1993, 1995, Little and Kitching 1996).

This study has shown that grazing by C. oculus was the primary factor controlling the recruitment and colonization by macroalgae and some invertebrates at Kalk Bay, and not physical factors associated with aerial exposure. These findings are consistent with Underwood (1980) who was the first to demonstrate experimentally that grazing was an important factor in determining the upper limits of algal colonization in Australia. Since then, such experimental evidence has increased internationally (e.g. Lubchenco 1980, Underwood and Jernakoff 1981, Lubchenco and Gaines 1981, Creese and Underwood 1982, Little and Kitching 1996, Anderson and Underwood 1997, Boaventura et al. 2002). Very little experimental evidence (e.g. Dye 1993, 1995) to this effect has, however, been reported for South African shores, despite the explicit mention of the importance of grazers in controlling species distributions (Branch and Branch 1981, Branch 1981, 1985b).

The data show that herbivory by C. oculus decreases algal diversity by preventing or inhibiting the recruitment and colonization of macroalgae in the mid-Eulittoral zone. The impacts of herbivores on algal assemblages are well documented (see e.g. Paine and Vadas 1969, Dayton 1971, Underwood 1980, Boaventura et al. 2002). It has long been suggested that grazers alter the rates of succession by either slowing down or speeding up the process (Dayton 1971, Farrell 1991, Sousa and Connell 1992). Paine and Vadas (1969) showed, for example, that when the sea urchin Strongylocentrotus purpuratus (Stimpson) was experimentally removed, algal diversity and succession increased dramatically. However, Anderson and Underwood (1997) suggested that grazers neither speed up nor slow down succession, but cause an entirely different assemblage to develop. In contrast to Anderson and Underwood (1997), and in support of Paine and Vadas (1969), this study has demonstrated that grazing by C. oculus decreases algal diversity and prevents algal succession.

The space cleared of $\mathrm{C}$. oculus also provided opportunities for the recruitment and colonization of a number of invertebrates. Dye (1995) illustrated that besides decreasing algal diversity, grazing by a number of herbivores prevented the recruitment of barnacles. Similarly, the exclusion of S. cochlear from its zone leads to the recruitment and colonization of other limpets and barnacles (Branch 1985b, 1985c). In this study, grazing by $\mathrm{C}$. oculus prevented the recruitment and colonization by the barnacles A. cylindricus and C. dentatus, the bryozoan W. subovoidea and the mussel 
M. galloprovincialis. Austromegabalanus cylindricus is usually only found infratidally and subtidally to at least $20 \mathrm{~m}$, or occasionally found forming thick mats on floating structures (Barnard 1924, Day 1969 [as Balanus maxillaries], Branch et al. 1994, Jones 2008). Chthamalus dentatus is commonly found on exposed flats in the upper intertidal zone, W. subovoidea subtidal to at least $20 \mathrm{~m}$ and beneath boulders and along shaded overhangs in the intertidal zone, and M. galloprovincialis in dense bands in the infratidal and low intertidal zone (Branch et al. 1994, Jones 2008). It was thus very interesting to find these invertebrates in our exclusion plots. Their presence suggested that they are capable of recruiting to the exposed rocky mid-intertidal platforms. The low densities of A. cylindricus and W. subovoidea, however, suggest that they do not recruit into the intertidal zone in large numbers. Since these latter two species appear to be rare anyway at this height on the shore, there could be other reasons explaining their appearance in conjunction with the exclusion of C. oculus. Spatial replication would be required to fully address this result.

Interestingly, some invertebrate species did not benefit from the absence of $\mathrm{C}$. oculus. While a few species (O. variegata, P. exigua, S. granularis) were not prevalent, still others (O. tigrina) never recruited into the exclusion plots. There may simply not have been sufficient time for these invertebrates to recruit into the exclusion plots. Alternatively, they may either have been outcompeted, or their larvae "grazed" by that herbivorous mollusc that benefited most from the exclusion of C. oculus. Other than the host of foliose macroalgae, the territorial gardening limpet S. longicosta and the encrusting brown alga $\mathrm{R}$. verrucosa benefited most by the exclusion of $\mathrm{C}$. oculus. Branch (e.g. 1976, 1981) had long ago established that there is a direct correlation between the density of S. longicosta (as Patella longicosta) and R. verrucosa cover, and that as much as $95 \%$ of R. verrucosa crusts encountered intertidally, occurred within the territories of S. longicosta. Branch (e.g. 1976, 1981) went on to suggest that the gardening behaviour of S. longicosta increases the productivity of the algal crust and that the territorial behaviour of this limpet was important in preventing the competitive exclusion of R. verrucosa by foliose macroalgae. This hypothesis was experimentally confirmed for the first time by McQuaid and Froneman (1993) who demonstrated it as a "clear example" of a marine facultative mutualism, examples of which are increasingly becoming apparent for the South African coastline (see e.g. Maneveldt and Keats 2008). McQuaid and Froneman (1993) went on to show that in the absence of S. longicosta (as P. longicosta), undefended algal crusts quickly disappeared due to overgrazing by nonterritorial limpets, primarily C. oculus (as P. oculus). The low densities of S. longicosta, combined with the relatively high densities of C. oculus within the Kalk Bay midEulittoral zone therefore probably accounted for the low cover abundance of R. verrucosa in our natural quadrats; this association and their prominence was no doubt restored when C. oculus was excluded.

This study has also shown that the natural density and biomass of C. oculus had increased dramatically within the first year of the study. This may be due to the study site at Kalk Bay becoming included in the Table Mountain National Park marine 
protected area (MPA) in J une 2004. Casual patrolling of the area by conservation officials had commenced at least a year ahead of this date. It is already well known that the density and biomass of limpets often increase substantially in MPAs compared to sites outside of MPAs (see e.g. Branch and Odendaal 2003, Lasiak 2006). Along with the brown mussel, Perna perna Linnaeus, the limpets S. barbara (Linnaeus), S. longicosta and C. miniata (Born), and the abalone Haliotis spadicea Donovan and $\mathrm{H}$. midae Linnaeus, C. oculus is one of the major targets by exploiters and poachers (Lasiak 1999, Proudfoot et al. 2006). This could possibly have been the reason for C. oculus' low density in previous years.

Cymbula oculus has not previously been mentioned as playing a major role in the midEulittoral zone, but rather S. longicosta with its garden of R. verrucosa (Branch 1976, Branch and Branch 1981, Branch 1981, 1985a, 1985b, McQuaid and Froneman 1993). In the mid-Eulittoral zone at Kalk Bay, however, C. oculus is clearly the dominant grazer, and despite many adult $\mathrm{C}$. oculus harbouring juvenile $\mathrm{S}$. longicosta on their shells, this association did not result in significant $\mathrm{S}$. longicosta recruitment onto the primary substratum. Cymbula oculus is known to be a generalist grazer, feeding on a range of low growing algae (including $R$. verrucosa), spume, lichens, organic debris and microalgae (Branch 1976). Kalk Bay is largely devoid of foliose macroalgae and so C. oculus' diet is probably largely comprised of the microalgal biofilm and the few remnants of $\mathrm{R}$. verrucosa. Scutellastra longicosta on the other hand, is a specialist grazer, feeding mainly on its garden of R. verrucosa (Branch 1976, 1981, McQuaid and Froneman 1993). While S. longicosta is a superior interference competitor (through bulldozing) to C. oculus (Branch 1976), the increasing density of C. oculus probably accounted for the low $\mathrm{S}$. longicosta numbers. We suspect that this may be due either to C. oculus consuming all the available food (through exploitative competition) including $\mathrm{R}$. verrucosa, consuming all the recruiting $\mathrm{S}$. longicosta larvae, or by sheer numbers with which S. longicosta can no longer compete.

In conclusion, this study has shown that herbivory by C. oculus is the primary biological factor preventing the recruitment and colonization by both macroalgae and some invertebrates. In addition, grazing by C. oculus prevents localized succession of macroalgae at Kalk Bay. Physical factors associated with desiccation stress thus appear to be of lesser importance in structuring this intertidal rocky shore community.

\section{Acknowledgements}

We thank the University of the Western Cape for providing funding, research facilities and technical support, the South African National Research Foundation (NRF) for research grants to GWM, and the South African Department of Environmental Affairs and Tourism (DEAT) for the research permits to carry out the investigation. Prof. Charles Griffiths (Zoology, University of Cape Town) provided valuable comments in the preparation of this manuscript. Thanks to Tamson Francis, Verno Gordon, Martin Hendricks and Liwalam Madikiza for assistance with field work. Special thanks are due to Frikkie Calitz, Marieta van der Rijst (Biometrics Unit, Agricultural Research Council) 
and Prof. IMR van Aarde (Biometry, University of Stellenbosch) for advice and assistance with the statistical analyses of the data.

\section{References}

Anderson MJ, Underwood AJ (1997) Effects of gastropod grazers on recruitment and succession of an estuarine assemblage: a multivariate and univariate approach. Oecologia 109: 442-453

Barnard KH (1924) Contributions to the Crustacean Fauna of South Africa. Annals of the South African Museum 20 (1): 1-103, pl 1

Boaventura D, Alexander M, Della Santini P, Smith ND, Ré P, da Fonseca LC, Hawkins SJ (2002) The effects of grazing on the distribution and composition of low-shore algal communities on the central coast of Portugal and on the southern coast of Britain. J ournal of Experimental Marine Biology and Ecology 267 (2): 185-206

Branch GM (1975) The Ecology of Patella from the Cape Peninsula South Africa. Zoologica Africana 10 (2): 133-162

Branch GM (1976) Interspecific competition experienced by South African Patella species. J ournal of Animal Ecology 45: 507-529

Branch GM (1981) The biology of limpets: physical factors, energy flow, and ecological interactions. Oceanography and Marine Biology Annual Review 19: 235-380

Branch GM (1985a) Competition: Its role in ecology and evolution in intertidal communities. In: Vrba ES (ed) Species and Speciation. Pretoria, Transvaal Museum, pp 97-104

Branch GM (1985b) Limpets: Their role in littoral and sublittoral community dynamics. In: Moore PG, Seed R (eds) The Ecology of Rocky Coasts. New York, Columbia University Press, pp 97-116

Branch GM (1985c) Limpets: Evolution and adaptation. The Mollusca 10: 187-217

Branch GM, Branch M (1981) The Living Shores of Southern Africa. Cape Town, Struik Publishers, $272 \mathrm{pp}$

Branch GM, Odendaal F (2003) The effects of marine protected areas on the population dynamics of a South African limpet, Cymbula oculus, relative to the influence of wave action. Biological Conservation 114 (2): 255-269

Branch GM, Griffiths CL, Branch ML, Beckley LE (1994) Two Oceans: A Guide to the Marine Life of Southern Africa. Cape Town, David Philip Publishers, 360 pp

Connell J H (1972) Community interactions on marine rocky intertidal shores. Annual Review of Ecology and Systematics 3: 169-192

Creese RG, Underwood AJ (1982) Analysis of inter- and intra-specific competition amongst intertidal limpets with different methods of feeding. Oecologia (Berlin) 53: 337-346 
Day JH (1969) A Guide to Marine Life on South African Shores. Cape Town, A.A. Balkema, $300 \mathrm{pp}$

Dayton PK (1971) Competition, disturbance and community organisation: The provision and subsequent utilisation of space in a rocky intertidal community. Ecological Monographs 41: 351-389

Dayton PK (1975) Experimental evaluation of ecological dominance in a rocky intertidal algal community. Ecological Monographs 45: 137-159

Dring MJ (1982) The Biology of Marine Plants. London, Edward Arnold, 199 pp

Dye AH (1993) Recolonization of intertidal macroalgae in relation to gap size and molluscan herbivory on a rocky shore on the east coast of southern Africa. Marine Ecology Progress Series 95(3): 263-271

Dye AH (1995) The effects of excluding limpets from the lower balanoid zone of rocky shores in Transkei, South Africa. South African J ournal of Marine Science 15: 9-15

Farrell TM (1991) Models and mechanisms of succession: An example from a rocky intertidal community. Ecological Monographs 61 (1): 95-113

Hawkins SJ, Harkin E (1985) Preliminary canopy removal experiments in algal dominated communities low on the shore and in the shallow subtidal on the Isle of Man. Botanica Marina 28 (6): 223-230

J ones G (2008) A field guide to the marine animals of the Cape Peninsula. Cape Town, Southern Underwater Research Group, $271 \mathrm{pp}$

Lasiak T (1999) The putative impact of exploitation on rocky infratidal macrofaunal assemblages: a multiple-area comparison. J ournal of Marine Biological Association of the United Kingdom 79 (2): 23-34

Lasiak T (2006) Spatial variation in density and biomass of patellid limpets inside and outside a marine protected area. J ournal of Molluscan Studies 72 (2): 137-142

Little C, Kitching JA (1996) The Biology of Rocky Shores. Oxford, Oxford University Press, $240 \mathrm{pp}$

Lubchenco J (1980) Algal zonation in the New England rocky intertidal community: An experimental analysis. Ecology 61 (2): 333-344

Lubchenco J, Gaines SD (1981) A unified approach to marine-plant herbivore interactions. I. Populations and communities. Annual Review of Ecology and Systematics 12: 405-437

Lubchenco J , Menge BA (1978) Community development and persistence in a low rocky intertidal zone. Ecological Monographs 59: 67-94

Maneveldt GW, Keats DW (2008) Effects of herbivore grazing on the physiognomy of the coralline alga Spongites yendoi and on associated competitive interactions. African J ournal of Marine Science 30 (3): 581-593 
McQuaid CD, Froneman PW (1993) Mutualism between the territorial intertidal limpet Patella longicosta and the crustose alga Ralfsia verrucosa. Oecologia 96: 128-133

Nicotri ME (1977) Grazing effects of four marine intertidal herbivores on the microflora. Ecology 58: 1020-1032

Paine RT, Vadas RL (1969) The effects of grazing by sea urchins, Strongylocentrous spp., on benthic algal populations. Limnology and Oceanography 14 (5): 710-719

Proudfoot L, Kaehler S, McGarry DK, Uppink PA, Aereboe M, Morris KM (2006) Exploitation status of infralittoral abalone (Haliotis midae) and alikreukel (Turbo sarmaticus) in the southern section of the Eastern Cape coast, South Africa. South African J ournal of Science 102: 162-168

Sousa WP, Connell J H (1992) Grazing and succession in marine algae. In: J ohn DM, Hawkins SJ, Price JH (eds) Plant-animal Interactions in the Marine Benthos. Oxford, Claredon Press, pp 425-441

Stephenson TA, Stephenson A (1949) The Universal features of zonation between tidemarks on rocky coasts. J ournal of Ecology 37: 289-305

Stephenson TA, Stephenson A (1972) Life Between Tidemarks on Rocky Shores. San Francisco, W. H. Freeman and Company, 425 pp

Raffaelli D, Hawkins S (1996) Intertidal Ecology. London, Chapman and Hall, 356 pp

Underwood AJ (1980) The effects of grazing by gastropods and physical factors on the upper limits of distribution of intertidal macroalgae. Oecologia 46: 201-213

Underwood AJ (1992) Competition and marine plant-animal interactions. In: J ohn DM, Hawkins SJ, Price JH (eds) Plant-animal Interactions in the Marine Benthos. Oxford, Claredon Press, pp 443-475

Underwood AJ, Jernakoff P (1981) Effects of interactions between algae and grazing gastropods on the structure of a low-shore intertidal algal community. Oecologia (Berlin) 48: 221-233

Underwood AJ, Jernakoff P (1984) The effects of tidal height, wave-exposure, seasonality and rock-pools on grazing and the distribution of intertidal macroalgae in New South Wales. J ournal of Experimental Marine Biology and Ecology 75 (1): 71-96 